(2) Open Access Full Text Article

REVIEW

\title{
Application of Topical Immunotherapy in the Treatment of Alopecia Areata: A Review and Update
}

This article was published in the following Dove Press journal:

Drug Design, Development and Therapy

\section{Thipprapai Mahasaksiri \\ Chaninan Kositkuljorn \\ Tanaporn Anuntrangsee (iD \\ Poonkiat Suchonwanit (D)}

Division of Dermatology, Department of Medicine, Faculty of Medicine,

Ramathibodi Hospital, Mahidol

University, Bangkok, Thailand
Correspondence: Poonkiat Suchonwanit Division of Dermatology, Department of Medicine, Faculty of Medicine, Ramathibodi Hospital, Mahidol University, 270 Rama VI

Road, Ratchathewi, Bangkok, I0400,

Thailand

Tel +66 2-20III II

Fax +66 2-20I-12II Ext 4

Email poonkiat@hotmail.com

\begin{abstract}
Treatment of extensive or recalcitrant alopecia areata (AA) is a major clinical challenge. Even after thorough investigation of several medications, its treatment outcomes have remained unsatisfactory. While there is no US Food and Drug Administration-approved medication for AA yet, topical immunotherapy has been a well-documented treatment option. Dinitrochlorobenzene, squaric acid dibutylester, and diphenylcyclopropenone are three substances that have demonstrated efficacy in the treatment of extensive or recalcitrant AA. Despite being commonly used, the mechanism underlying topical immunotherapy is not well-elucidated and a wide range of clinical efficacies have been reported in the literature. The aim of this review was to summarize and update the pharmacology, mechanism of action, therapeutic efficacy, and tolerability of topical immunotherapy in the treatment of AA.
\end{abstract}

Keywords: contact sensitizers, dinitrochlorobenzene, diphencyprone, diphenylcyclopropenone, hair loss, squaric acid dibutylester

\section{Introduction}

Alopecia areata (AA) is a common nonscarring alopecia with a worldwide prevalence of $0.1-0.2 \%$. It is characterized by a patch or multiple patches of hair loss, diffuse or complete hair loss, occurring on the scalp or other body areas and presenting with or without exclamation mark hairs. ${ }^{1,2} \mathrm{AA}$ is theorized as a hair follicle-specific autoimmune disease with a genetic predisposition, progressing from disruption of immune privilege of hair follicles. ${ }^{3}$ Due to its nature, up to $25 \%$ of patients are recalcitrant to therapy and recurrence rate is as high as $13.5-33 \%$ in patients. ${ }^{4}$ Several therapeutic modalities have been examined to date; however, treatment responses were variable and unpredictable. ${ }^{5-10}$ Moreover, side effects from medications used, especially from corticosteroids, are major concerns in long-term therapy. Although no treatment for AA has been approved by US Food and Drug Administration yet, appropriate modalities are essential considering the associated psychological consequences, including anxiety and depression. $^{11,12}$

Currently, topical immunotherapy offers the best efficacy and safety regarding long-term treatment of patients with recalcitrant AA. ${ }^{13}$ It enables hair regrowth by inducing an inflammatory response to contact sensitizing agents at the applied area. Most of the published studies have reported response rates between 9 and $87 \%$, with an effective rate of approximately $30 \%$, which is considered worthwhile. ${ }^{14}$ Regardless of its popularity, the underlying mechanism of AA treatment is not fully 
elucidated. The aim of this review was to summarize and update the pharmacology, mechanism of action, clinical efficacy, and adverse events of topical immunotherapy in the treatment of AA.

\section{Role of Pro-inflammatory Cytokines in Pathogenesis of Alopecia Areata}

The pathomechanism of AA involves the complex interaction between innate and adaptive immunities. ${ }^{15}$ Its immunohistochemistry showed peri- and intrafollicular infiltration of $\mathrm{CD}^{+}$and $\mathrm{CD}^{+} \mathrm{T}$ cells at the bulb of affected the hair follicle. While $\mathrm{CD} 4^{+} \mathrm{T}$ cells were located mostly in the peri-follicular area, $\mathrm{CD}^{+} \mathrm{T}$ cells penetrated to the intrafollicular area, thereby disrupting the hair growth cycle. ${ }^{3}$ Recent hypothesis of the disease mechanism focuses on the collapse of immune privilege of hair follicles and autoreactive lymphocytes. Under normal conditions, hair follicles form an area where autoantigens cannot be recognized due to the lack of major histocompatibility complex (MHC) in the proximal outer root sheath and matrix cells. ${ }^{16,17}$ In AA, the immune privilege is disrupted by specific triggers, such as microtrauma, viral infection, or endocrine dysfunction, resulting in immune dysregulation. ${ }^{18}$ Further, ectopic expression of MHC class I, recognized by autoreactive $\mathrm{CD}^{+} \mathrm{T}$ cells, could directly and adversely affect anagen hair follicles, leading to follicular apoptosis. $^{18}$

Several studies have demonstrated the role of inflammatory cytokines, especially Th1-mediated cytokines, in the occurrence of AA via two possible mechanisms, either activation of the $\mathrm{CD}^{+} \mathrm{T}$ cell pathway or induction of cessation of hair growth cycle. Interferon (IFN)- $\gamma$, the hallmark cytokine of Th1-mediated pathway, is regarded as a key cytokine in AA. ${ }^{16,19}$ A large amount of IFN- $\gamma$ is produced by autoactivated $\mathrm{CD}^{+}$cells and antigen presenting cells (APCs) after initial inflammatory insult on hair follicles, ${ }^{20-27}$ resulting in further upregulation of $\mathrm{MHC}$ class I and II molecules in the bulb of hair follicles and activation of $\mathrm{CD}^{+}$and $\mathrm{CD}^{+}{ }^{\mathrm{T}}$ cells. ${ }^{28}$ Serum from patients has been reported to contain a higher level of IFN- $\gamma$, interleukin (IL)-2, IL-12, and IL-18 compared to that from control subjects. ${ }^{29,30}$ Serum levels of IFN- $\gamma$ tend to be elevated with disease severity. ${ }^{19,31}$ IL-1B, IL-2, and IL-6 are also present in human scalp lesions. ${ }^{32}$ Furthermore, the Th17 pathway may be involved in disease development by collaboration with the Th1 pathway via IL-17A and IL-17F. ${ }^{33}$
Recent studies have reported significantly increased serum levels of Th2 cytokines, such as IL-4 and IL-10, which were suspected to be critical players in disease suppression. Serum level of IL-4 was found to be higher in patients with patch-type AA, a mild form of the disease, than in those with other subtypes. ${ }^{29}$ Apart from the Th2-mediated pathway, regulatory $\mathrm{T}$ cells are also responsible for the suppression of exaggerated Th1- and Th2-related inflammation via TGF- $\beta$ and IL-10. ${ }^{31}$ Without a definite conclusion about its mechanism, the majority of the studies have shown no significant difference in regulatory cytokines between patients with AA and normal controls. ${ }^{31,34-40}$

\section{Topical Immunotherapy and Alopecia Areata}

Topical immunotherapy has been adopted for the treatment of several immune-mediated skin diseases since the $1970 \mathrm{~s}$. This modality is recommended as the first-line treatment in severe and recalcitrant AA due to its high efficacy and relatively low rate of adverse effects, as shown in previous reports. ${ }^{5,41-44}$ The potential role of topical immunotherapy in the treatment of AA has been demonstrated for decades and various substances have been introduced for the purpose. ${ }^{45}$ In this review, we have emphasized three commonly prescribed agents, namely dinitrochlorobenzene (DNCB), squaric acid dibutylester (SADBE), and diphenylcyclopropenone (diphencyprone, DPCP). ${ }^{46}$

\section{Mechanism of Topical Immunotherapy in Alopecia Areata}

Various theories exist regarding the mechanisms of immunotherapy for the treatment of AA. The main mechanism focuses on antigenic competition using immunomodulators to induce allergic contact dermatitis at the applied area through delay-type hypersensitivity. ${ }^{47}$ The substance acts as hapten, which binds to endogenous protein, forming a complete antigen. This complex is detected by APCs, and activates antigen-specific $\mathrm{T}$ cells causing the clinical condition of dermatitis. ${ }^{48}$ With the elicitation of an allergic reaction, suppressor $\mathrm{T}$ cells are generated, which infiltrate around hair follicles in the late phase. These newly infiltrating $\mathrm{T}$ cells, mainly expressing $\mathrm{CD} 8^{+}$and $\mathrm{CD} 1 \mathrm{a}^{+}$, act against the autonomous $\mathrm{CD}^{+}$and $\mathrm{CD}^{+} \mathrm{T}$ cell populations, and disturb APC migration at the affected follicles. ${ }^{49}$ A decrease in $\mathrm{CD}^{+} \mathrm{T}$ cells and increase in $\mathrm{CD}^{+} \mathrm{T}$ cells in the treated area results in an alteration of lymphocyte perifollicular pattern, with a decrease in the ratio of $\mathrm{CD}^{+}$to $\mathrm{CD} 8^{+}$ 
T cells from 4:1 to 1:1. MHC class I and II expression also declined after treatment with topical immunotherapy. ${ }^{50}$ A molecular study demonstrated that topical immunotherapy can induce the expression of immunoregulatory molecules, such as cytotoxic T-lymphocyte-associated protein 4, forkhead box P3, and indoleamine 2,3-dioxygenase. ${ }^{51}$ Hence, improvement of local immunoregulation could promote hair regrowth in patients with $\mathrm{AA} .{ }^{47}$ However, all of these T-cellmediated mechanisms are supposed to be modulated by counteracting inflammatory cytokines and growth factors, especially Th1 cytokines. ${ }^{16,52}$

Another mechanism regarding cytokine alteration has also been proposed. Previous studies had suggested that Th1 cytokines, such as IFN- $\gamma$, IL-1 $1 \beta$, and IL-2, were elevated in untreated patients with AA. However, after receiving treatment with topical immunotherapy, levels of IFN- $\gamma$ and IL-12, and Th17 cytokines reduced along with increase in regulatory cytokines, namely IL-2, IL-4, IL-8, and IL-10, and tumor necrosis factor (TNF)- $\alpha$, in both serum and scalp biopsy specimens. ${ }^{50,52-54}$ Application of DPCP was demonstrated to increase mRNA expression of IL-2, IL-8, IL-10, and TNF- $\alpha .{ }^{34} \mathrm{IL}-10$ has been theorized as a key factor for the effectiveness of immunotherapy by inhibiting $\mathrm{T}$ lymphocytes. ${ }^{34}$ However, additional studies would be required to confirm the role of regulatory cytokines in AA, since Lee et al had reported no significant difference in the IL-10 levels of scale samples from patients (responders vs nonresponders) after receiving topical immunotherapy. ${ }^{55}$ Gong et al demonstrated that patients with pretreatment showed elevated Th1-cytokines, using IL-12 as the marker, and could be good candidates for DPCP therapy. Patients with elevated Th2-cytokines, such as IL-4, can counteract the immune response elicited by topical immunotherapy, leading to poor treatment response. ${ }^{56}$

In summary, there are two possible mechanisms of topical immunotherapy in the treatment of AA. The first involves antigenic competition, which shifts the target of $\mathrm{T}$ cells from hair follicles to the epidermis. The second involves cytokine alteration, which increases in T-regulatory lymphocytes causing decline of follicular immune reaction. However, these two mechanisms would require further evidence in order to establish their roles in the treatment of AA.

\section{Treatment Protocol for Alopecia Areata with Topical Immunotherapy}

There is a standard protocol for all topical sensitizing agents used in the treatment of AA. Substances are commercially available either in powder form or as an acetone solution. To preserve their therapeutic properties, the agents need to be stored in amber glass at a temperature of $4^{\circ} \mathrm{C}$ and kept away from sunlight. ${ }^{57}$ Patients are initially sensitized with $2 \%$ solution applied on a $4 \times 4 \mathrm{~cm}$ area on the upper arm or on the scalp. After two weeks of sensitization, treatment begins with a weekly application of the substance, starting from the lowest concentration (usually $0.01 \%$ ) on one side of the scalp while the other side serves as the control. It is necessary to avoid sunlight and washing of the scalp for 48 $\mathrm{h}$ after the application. Weekly increase in the concentration of substance may be necessary for maintaining optimal eczematous reaction (tolerable itching and erythema). The concentration should be carefully adjusted by following the reaction. Once hair regrowth becomes obvious on the treated side, the substance may be applied on the entire scalp. Hair regrowth is expected between three and six months of treatment and should be discontinued if no regrowth occurs after six months. ${ }^{58,59}$

\section{Dinitrochlorobenzene}

DNCB or 1-chloro-2,4-dinitrobenzene was the earliest contact allergen introduced in 1912. Its chemical structure is $\mathrm{C}_{6} \mathrm{H}_{3} \mathrm{Cl}\left(\mathrm{NO}_{2}\right)_{2}$ (Figure 1). It used to be popular for the treatment of extensive or recalcitrant $\mathrm{AA}$, with hair regrowth ranging around $25-89 \%$ and complete regrowth rates being $6.7-25 \%$. However, in 1985, DNCB was found to be mutagenic and carcinogenic in Ames test and had to be discontinued thereafter. ${ }^{60}$ Clinical trials using DNCB for the treatment of AA are listed in Table $1 .{ }^{61-65}$

\section{Squaric Acid Dibutylester}

SADBE or 3,4-dibutoxycyclobut-3-ene-1,2-dione is a sensitizing agent with chemical structure $\mathrm{C}_{12} \mathrm{H}_{18} \mathrm{O}_{4}$ (Figure 2). Its efficacy in AA treatment was first reported in

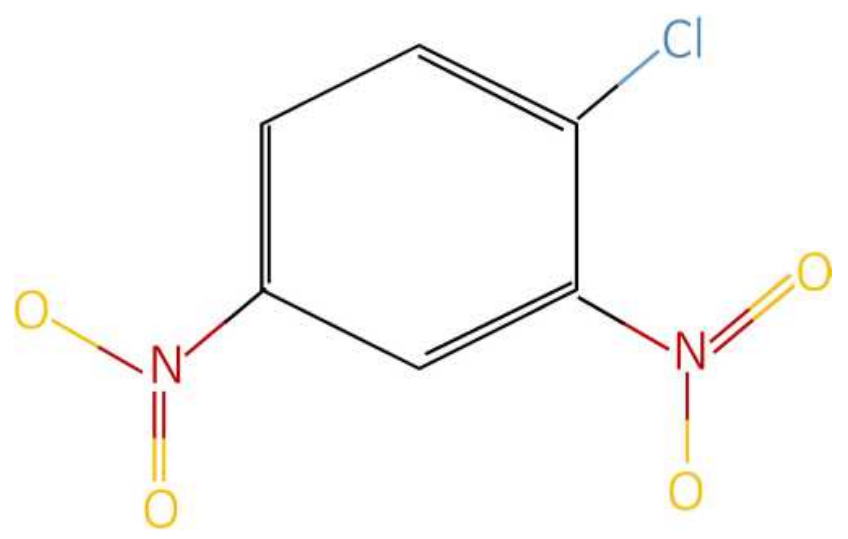

Figure I Chemical structure of dinitrochlorobenzene. 


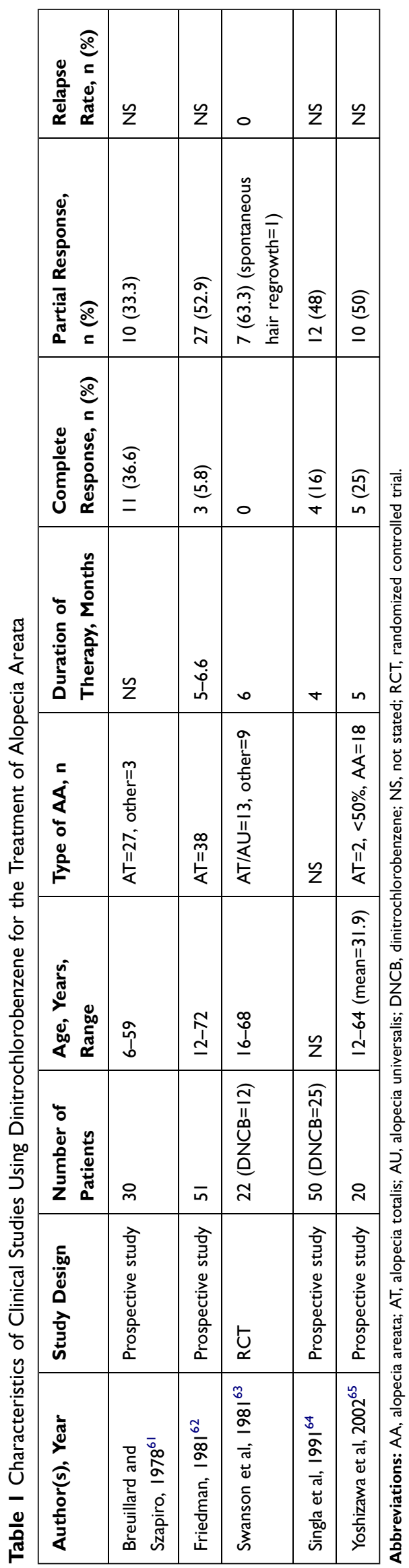

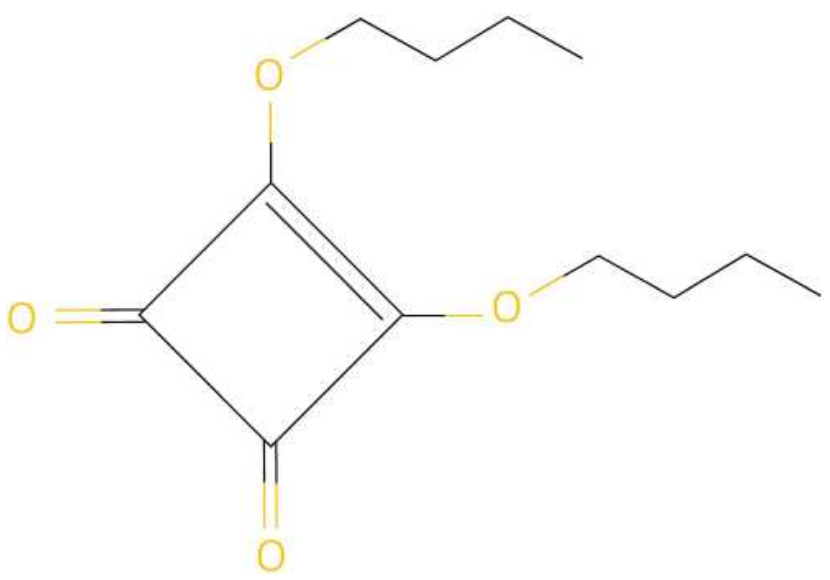

Figure 2 Chemical structure of squaric acid dibutyl ester.

1980. ${ }^{66} \mathrm{SADBE}$ is an ideal sensitizing agent due to its absence in the environment and lack of cross-reaction with other agents. However, it is unstable in acetone solution and can degrade within a few hours at room temperature. To circumvent this issue, a light-resistant temperature-controlled container is used for sustaining its maximum effect. ${ }^{67}$

The response rate of SADBE in the treatment of AA ranges between $19 \%$ and $79.6 \%$. A meta-analysis by Lee et al, including 45 studies with 2227 patients, showed $51.8 \%$ of patients with patch-type AA and $25 \%$ of patients with alopecia totalis (AT)/alopecia universalis (AU) to have achieved satisfactory hair regrowth. ${ }^{68} \mathrm{~A}$ network meta-analysis by Gupta et al suggested that $35 \%$ and $49.7 \%$ of patients with patch-type AA and AT/AU, respectively, demonstrated satisfactory hair regrowth. ${ }^{69}$

One randomized placebo-controlled trial of SADBE was published in 1986, which demonstrated complete hair regrowth in $64 \%$ of patients with patch-type $\mathrm{AA} .{ }^{70}$ The largest prospective study of SADBE, conducted in 144 patients with variable severities of AA, reported $80 \%$ and $49 \%$ response rates in mild and severe forms of AA, respectively. ${ }^{71}$ Satisfactory results were reported by Happle et al, Dall'oglio et al, and Chua et al, with complete hair regrowth rates of $87 \%, 79.6 \%$, and $68 \%$, respectively. ${ }^{66,72,73}$ In contrast, Caserio and Gianetti and Orecchia reported unsatisfactory results with complete response rate of $28.5 \%$ and $19 \%$, respectively. ${ }^{74,75}$ Characteristics of clinical studies using SADBE for the treatment of AA have been summarized in Table 2. ${ }^{66,68,69,71-82}$

Adverse effects of SADBE include redness, swelling, and itching at the application site. However, some patients might experience more severe reactions, such as blistering, burning of the skin, and spreading of rash to other areas. 
Table 2 Characteristics of Clinical Studies Using Squaric Acid Dibutylester for the Treatment of Alopecia Areata

\begin{tabular}{|c|c|c|c|c|c|c|c|c|}
\hline $\begin{array}{l}\text { Author(s), } \\
\text { Year }\end{array}$ & $\begin{array}{l}\text { Study } \\
\text { Design }\end{array}$ & $\begin{array}{l}\text { Number } \\
\text { of } \\
\text { Patients }\end{array}$ & $\begin{array}{l}\text { Age, } \\
\text { Years, } \\
\text { Range }\end{array}$ & Type of AA, $n$ & $\begin{array}{l}\text { Duration of } \\
\text { Therapy, } \\
\text { Months }\end{array}$ & $\begin{array}{l}\text { Complete } \\
\text { Response, } \\
\text { n (\%) }\end{array}$ & $\begin{array}{l}\text { Partial } \\
\text { Response, } \\
\text { n (\%) }\end{array}$ & $\begin{array}{l}\text { Relapse } \\
\text { Rate, } \\
\text { n (\%) }\end{array}$ \\
\hline $\begin{array}{l}\text { Happle et al, } \\
1980^{66}\end{array}$ & $\begin{array}{l}\text { Prospective } \\
\text { study }\end{array}$ & 53 & $6-57$ & $\begin{array}{l}\text { AT } / A U=27, \\
\text { other }=26\end{array}$ & $6-15$ & $46(87)$ & NS & $9(19.6)$ \\
\hline $\begin{array}{l}\text { Giannetti and } \\
\text { Orecchia, } \\
1983^{75}\end{array}$ & $\begin{array}{l}\text { Prospective } \\
\text { study }\end{array}$ & 26 & $6-32$ & $\begin{array}{l}A T / A U=6,>50 \% \\
A A=12,<50 \% \\
A A=8\end{array}$ & NS & $5(19)$ & $12(46)$ & NS \\
\hline $\begin{array}{l}\text { Tosti et al, } \\
1986^{76}\end{array}$ & RCT & 44 & $5-74$ & $P A=44$ & NS & $28(64)$ & NS & I (3.5) \\
\hline $\begin{array}{l}\text { Johansson et al, } \\
1986^{77}\end{array}$ & $\begin{array}{l}\text { Prospective } \\
\text { study }\end{array}$ & 19 & $14-55$ & $\begin{array}{l}\text { AT } / A U=13, \\
\text { other }=6\end{array}$ & 4 & $8(42.1)$ & II (58) & NS \\
\hline $\begin{array}{l}\text { Caserio et al, } \\
1987^{74}\end{array}$ & $\begin{array}{l}\text { Prospective } \\
\text { study }\end{array}$ & 14 & $\begin{array}{l}7-66 \\
(\text { mean=16.5) }\end{array}$ & $\mathrm{AT} / \mathrm{AU}=12, \mathrm{PA}=2$ & $6.5-10.5$ & $4(28.5)$ & $7(50)$ & I (9.1) \\
\hline $\begin{array}{l}\text { Orecchia et al, } \\
1994^{79}\end{array}$ & $\begin{array}{l}\text { Prospective } \\
\text { study }\end{array}$ & 28 & $5-13$ & $\begin{array}{l}A T / A U=11, \\
P A=17\end{array}$ & $5-10$ & $9(32.1)$ & $6(21.4)$ & $14(93.3)$ \\
\hline $\begin{array}{l}\text { Tosti et al, } \\
1996^{80}\end{array}$ & $\begin{array}{l}\text { Prospective } \\
\text { study }\end{array}$ & 33 & $6-14$ & $A T=10, A U=23$ & $\begin{array}{l}4-22 \\
(\text { mean=12.8) }\end{array}$ & $10(30.3)$ & $6(18)$ & 7 (43.8) \\
\hline $\begin{array}{l}\text { Chua et al, } \\
1996^{73}\end{array}$ & $\begin{array}{l}\text { Prospective } \\
\text { study }\end{array}$ & 19 & $14-42$ & $\begin{array}{l}A T / A U=7, \\
\text { mixed }=12\end{array}$ & 6 & $13(68)$ & $2(\mathrm{II})$ & $\begin{array}{l}33 \% \text { in } \\
\text { AT } \\
11 \% \text { in } \\
\text { AA }\end{array}$ \\
\hline $\begin{array}{l}\text { Micali et al, } \\
1996^{71}\end{array}$ & $\begin{array}{l}\text { Prospective } \\
\text { study }\end{array}$ & 144 & $\begin{array}{l}5-50 \\
(\text { mean=23) }\end{array}$ & $\begin{array}{l}\text { AT/AU }=15 \\
<50 \%, A A=7 \mid \\
\text { other }=58\end{array}$ & 12 & NS & $\begin{array}{l}80 \% \text { less } \\
\text { severe form } \\
49 \% \text { severe } \\
\text { form }\end{array}$ & NS \\
\hline $\begin{array}{l}\text { lijima and } \\
\text { Otsuka, } 1997^{81}\end{array}$ & $\begin{array}{l}\text { Prospective } \\
\text { study }\end{array}$ & 48 & $6-57$ & $\begin{array}{l}A T / A U=14, \\
P A=3 I, A O=3\end{array}$ & 6 & $23(48)$ & $20(41.6)$ & NS \\
\hline $\begin{array}{l}\text { Dall'oglio et al, } \\
2005^{72}\end{array}$ & $\begin{array}{l}\text { Prospective } \\
\text { study }\end{array}$ & 54 & $4-7 \mid$ & $\begin{array}{l}A T / A U=13, \\
P A=89, \quad A O=5\end{array}$ & $24-96$ & $\begin{array}{l}43(79.6) \\
\text { total } \\
73 \% \text { in adults } \\
100 \% \text { in } \\
\text { children }\end{array}$ & NS & $44 \%$ \\
\hline $\begin{array}{l}\text { Lee et al, } \\
2018^{68}\end{array}$ & \multicolumn{2}{|l|}{ Meta-analysis } & \multicolumn{2}{|c|}{$\begin{array}{l}45 \text { studies (DPCP } 3 \text { I studies, } \\
\text { SADBE I } 5 \text { studies, DPCP+SADBE } \\
\text { I study) }\end{array}$} & \multicolumn{4}{|c|}{$\begin{array}{l}\text { Satisfactory hair regrowth (>75\% hair regrowth) } 38.4 \% \text { (PA } \\
51.8 \% \text {, AT/AU } 25 \% \text { ) } \\
\text { CR } 38.4 \% \text { (PA } 50.5 \%, \text { AT/AU } 35 \% \text { ) }\end{array}$} \\
\hline $\begin{array}{l}\text { Sakai et al, } \\
2019^{82}\end{array}$ & $\begin{array}{l}\text { Retrospective } \\
\text { cohort study }\end{array}$ & 49 & $3-74$ & $\begin{array}{l}A T / A U=16,>50 \% \\
A A=20,<50 \% \\
A A=13\end{array}$ & $6-12$ & II (57.8) & $22(45)$ & NS \\
\hline $\begin{array}{l}\text { Gupta et al, } \\
2019^{69}\end{array}$ & \multicolumn{2}{|l|}{ Meta-analysis } & \multicolumn{2}{|c|}{$\begin{array}{l}38 \text { studies (PA II studies, AT/AU } \\
27 \text { studies) }\end{array}$} & \multicolumn{4}{|c|}{$\begin{array}{l}35 \% \text { Satisfactory hair regrowth ( }>70 \% \text { hair regrowth) in PA } \\
49.7 \% \text { Satisfactory hair regrowth }(>70 \% \text { hair regrowth) in } \\
\text { AT/AU }\end{array}$} \\
\hline
\end{tabular}

Abbreviations: AA, alopecia areata; AO, alopecia ophiasis; AT, alopecia totalis; AU, alopecia universalis; CR, complete regrowth; DPCP, diphenylcyclopropenone; NS, not stated; PA, patch-type alopecia areata. 


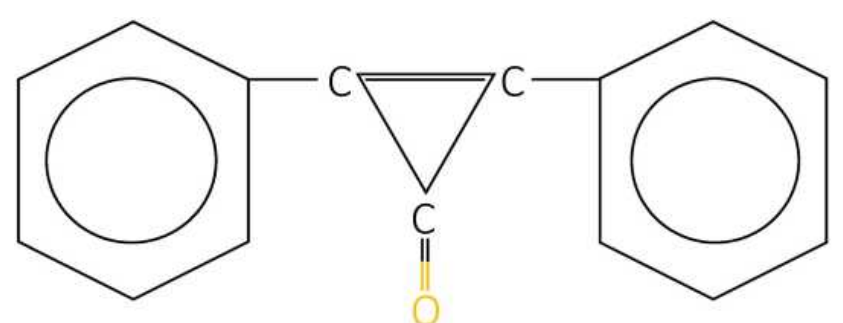

Figure 3 Chemical structure of diphenylcyclopropenone.

Uncommon adverse effects reported include spread of generalized eczema, persistent contact dermatitis, and severe angioedema. ${ }^{83-86}$ Postinflammatory hypopigmentation and depigmentation have also been reported after the application of SADBE, and lesions were obviously visible in patients with skin phototype V or VI. ${ }^{87,88}$

\section{Diphenylcyclopropenone}

DPCP is a topical sensitizer, efficacy of which was primarily reported by Happle et al in $1983 .{ }^{89}$ Its chemical structure is $\mathrm{C}_{15} \mathrm{H}_{10} \mathrm{O}$ (Figure 3). Currently, DPCP is the most commonly used substance owing to the following reasons. First, it is nonmutagenic in Ames assay, with no report of systemic absorption. ${ }^{45}$ Second, no long-term adverse effect has been documented yet. Finally, it is less expensive and more stable in acetone solution compared to SADBE. ${ }^{90}$ In 2012, the British Association of Dermatologists' guideline also recommended the use of DPCP as the first-line topical sensitizer for the treatment of $\mathrm{AA}^{42}$

Several studies have evaluated the efficacy of DPCP in patients with AA; hair regrowth rate was found to be 6-77\%. A systematic review had previously reported an overall hair regrowth rate of $53.75 \%$ in DPCP-treated patients. ${ }^{91}$ Severity of AA was found to be a significant factor associated with hair regrowth. The highest efficacy of DPCP was reported by Tosti et al with $77 \%$ complete hair regrowth in patients with mild $\mathrm{AA} .^{70}$ The largest retrospective study involving 757 patients with all subtypes of AA was published in $2020 .{ }^{92}$ The overall hair regrowth rate has been reported to be $60.1 \%$ and the satisfactory hair regrowth ( $>75 \%$ hair regrowth) rate was $16.3 \%$. Comparison across subtypes of AA showed patchtype AA to have 2.56 times higher satisfactory hair regrowth while AU had 2.6 times lower response in comparison to other subtypes. ${ }^{92}$ The satisfactory hair regrowth rate of DPCP for patch-type AA was reported ranging between $55.4 \%$ and $63.4 \% .{ }^{68,69}$ When the efficacy of
DPCP on AT/AU subtype was considered, two meta-analyses showed different results. Lee et al reported $28.3 \%$ of patients with satisfactory hair regrowth while Gupta et al reported a higher rate of $87.9 \%{ }^{68,69}$

Very few studies to date have demonstrated the efficacy of DPCP in children with AA. The efficacy of satisfactory hair regrowth has been reported to range from $11-33 \%$. A prospective study using DPCP in 12 pediatric patients with extensive AA reported initial hair regrowth in $67 \%$ of patients and complete hair regrowth in 33\% after a mean treatment duration of 7.3 months. ${ }^{93}$ Another retrospective study investigated the efficacy of DPCP in 108 children with AA, and found only $13 \%$ and $11 \%$ of patients to have achieved complete hair regrowth after six and 12 months of treatment, respectively. ${ }^{94}$

Although efficacy of DPCP has been widely investigated for hair regrowth, few studies have focused on the relapse rate after cessation of treatment. A comparative study in this regard showed that patients who continued using DPCP as a maintenance therapy had a lower relapse rate $(24.4 \%)$ compared to those who did not (68.2\%). ${ }^{95}$ Hull and Cunliffe reported $63 \%$ relapse rate after six months of successful therapy without maintenance treatment. Male gender, high severity of disease, and body hair involvement were established as negative factors determining recurrence. ${ }^{96}$ In contrast, a study on 25 patients with complete hair regrowth showed no relapse after discontinuing DPCP, over a mean period of 15 months. ${ }^{97}$ The importance of maintenance therapy in topical immunotherapy still remains inconclusive. Clinical studies of DPCP in the treatment of AA have been summarized in Table $3 .^{43,53,68,69,76,89,91-94,96,98-114}$

\section{Diphenylcyclopropenone in Combination with Other Treatments}

Use of DPCP as a combination therapy was attempted in several studies for the purpose of enhanced efficacy. Combination therapy using DPCP and anthralin demonstrated higher efficacy over DPCP monotherapy, since one study reported complete hair regrowth in $72 \%$ and $36.4 \%$ of patients with combined therapy and monotherapy, respectively. ${ }^{115}$ On the contrary, two studies and one case series showed nonsuperior efficacy of DPCP and anthralin combination therapy compared to DPCP monotherapy. ${ }^{116-118}$ Regarding its combination with 5\% minoxidil, Shapiro et al found no significant difference in satisfactory hair regrowth between combined regimen and DPCP monotherapy. ${ }^{119}$ When combined with 


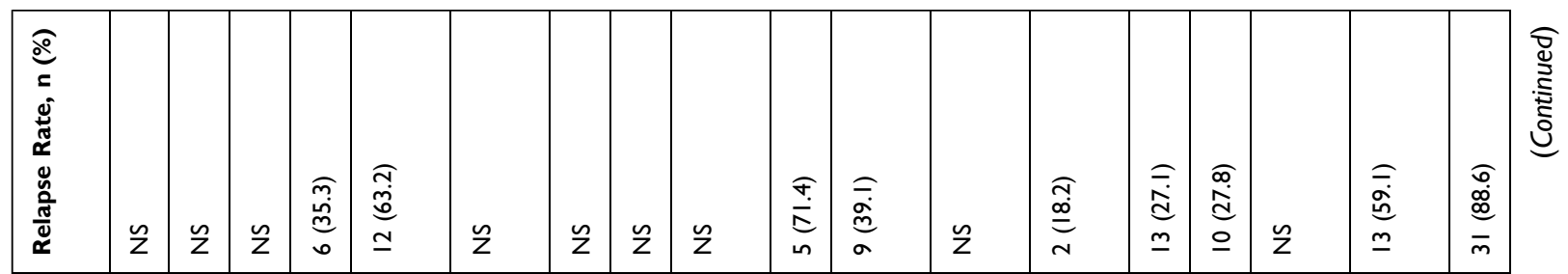

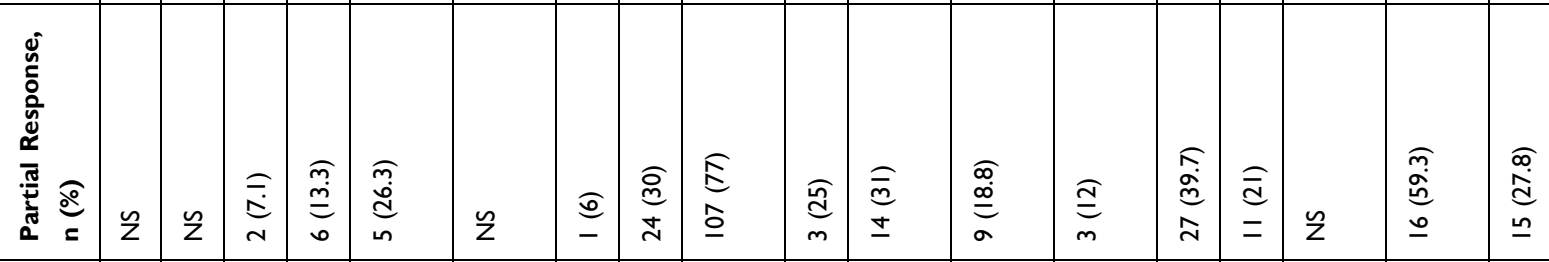

\begin{tabular}{|c|c|c|c|c|c|c|c|c|c|c|c|c|c|c|c|c|c|}
\hline 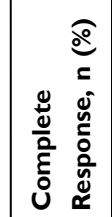 & 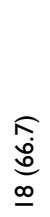 & $\begin{array}{l}E \\
\hat{N}\end{array}$ & 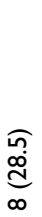 & $\begin{array}{l}\overrightarrow{\mathbb{d}} \\
\stackrel{d}{d} \\
=\end{array}$ & $\begin{array}{l}\widehat{\sigma} \\
\stackrel{\tilde{D}}{0} \\
\underline{\Xi}\end{array}$ & 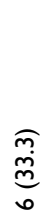 & $\stackrel{\widehat{e}}{-}$ & $\begin{array}{l}\text { శ్ల్య } \\
\text { బ్ }\end{array}$ & $\begin{array}{l}\text { Fे. } \\
\text { 员 } \\
\text { R }\end{array}$ & 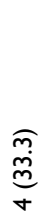 & ্ֻৰे & $\begin{array}{l}\widehat{\underline{n}} \\
\stackrel{m}{\infty} \\
\underline{\infty}\end{array}$ & 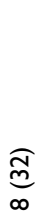 & $\begin{array}{l}\text { बे } \\
\text { ô } \\
\bar{\alpha}\end{array}$ & 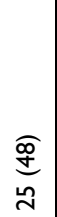 & 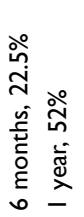 & $\begin{array}{l}\widehat{\mathbb{d}} \\
\stackrel{\mathbb{d}}{0}\end{array}$ \\
\hline
\end{tabular}

\begin{tabular}{|c|c|c|c|c|c|c|c|c|c|c|c|c|c|c|c|c|c|c|c|}
\hline & 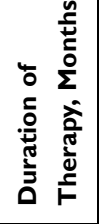 & $\bar{\jmath}$ & $\Sigma$ & $\infty$ & $\begin{array}{l}\infty \\
\vdots \\
n\end{array}$ & $\bar{j}$ & 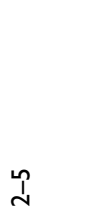 & $\begin{array}{l}\stackrel{n}{\sim} \\
\stackrel{\tilde{g}}{\tilde{g}} \\
\frac{\tilde{\sigma}}{\dot{\alpha}}\end{array}$ & 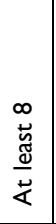 & $\tilde{z}$ & 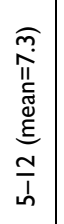 & $\begin{array}{l}\underset{y}{J} \\
\stackrel{\leftrightarrow}{N}\end{array}$ & 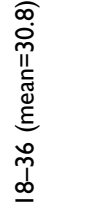 & 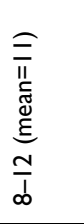 & 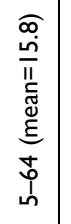 & $\frac{1}{b}$ & 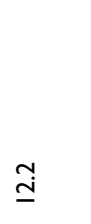 & $\stackrel{ \pm}{\sim}$ & 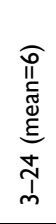 \\
\hline & 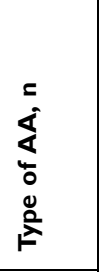 & 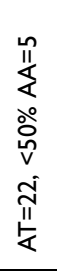 & 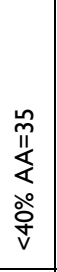 & $\Sigma$ & 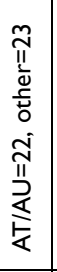 & 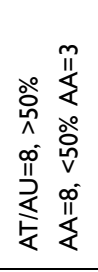 & 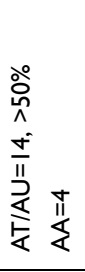 & $\begin{array}{l}0 \\
11 \\
\frac{11}{4} \\
\infty \\
11 \\
\frac{1}{<}\end{array}$ & 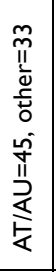 & 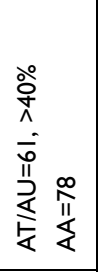 & 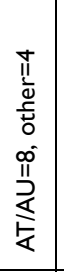 & 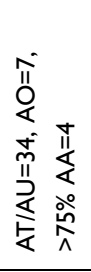 & 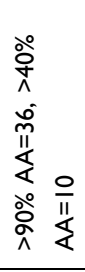 & 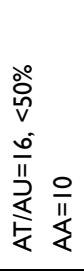 & 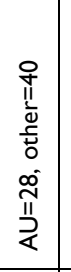 & 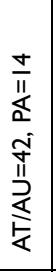 & 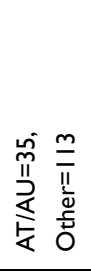 & 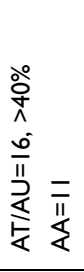 & 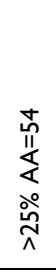 \\
\hline & 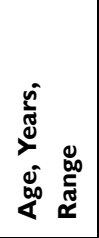 & $\begin{array}{l}\text { 占 } \\
\underline{\underline{n}}\end{array}$ & $\Sigma$ & 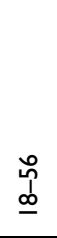 & 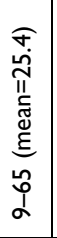 & $\begin{array}{l}\stackrel{\Delta}{\stackrel{p}{\prime}} \\
\underline{-}\end{array}$ & 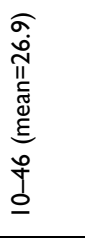 & $\underset{\Lambda}{\mathbb{N}}$ & $\tilde{z}$ & $\underset{j}{\hat{\nu}}$ & 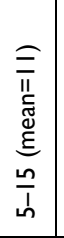 & 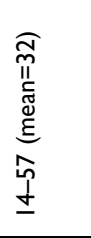 & $\begin{array}{l}\text { t } \\
\text { I }\end{array}$ & 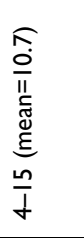 & 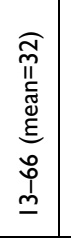 & 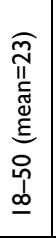 & 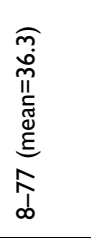 & 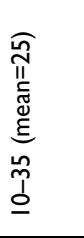 & 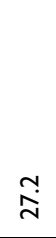 \\
\hline
\end{tabular}

\begin{tabular}{|c|c|c|c|c|c|c|c|c|c|c|c|c|c|c|c|c|c|}
\hline 至 & $\hat{\lambda}$ & 耑 & $\stackrel{\infty}{\sim}$ & \& & $\underline{\sigma}$ & $\underline{\infty}$ & 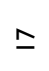 & $\stackrel{\infty}{\sim}$ & $\stackrel{a}{\underline{m}}$ & $\simeq$ & \& & $\stackrel{\infty}{\leftarrow}$ & $\stackrel{\sim}{\sim}$ & $\infty$ & กี & 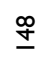 & $\hat{\lambda}$ \\
\hline 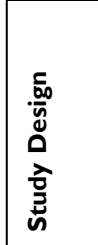 & 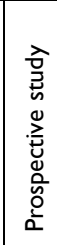 & 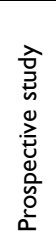 & 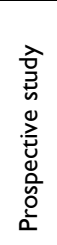 & 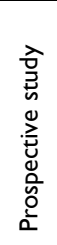 & 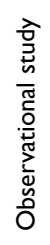 & 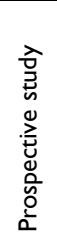 & 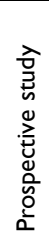 & 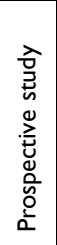 & 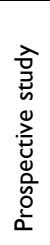 & 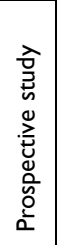 & 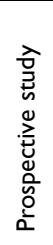 & 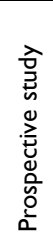 & 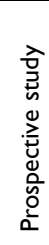 & 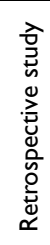 & 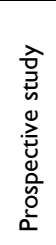 & 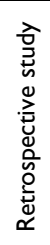 & 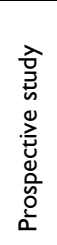 \\
\hline 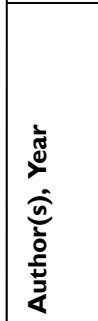 & 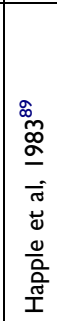 & 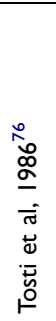 & 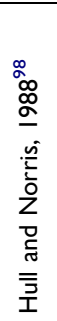 & 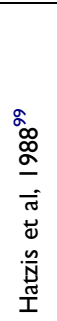 & 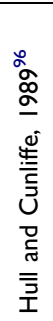 & 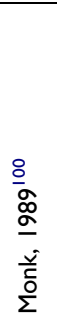 & 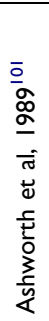 & 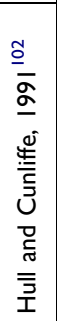 & 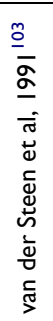 & 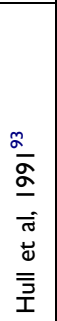 & 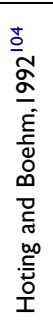 & 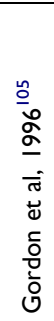 & 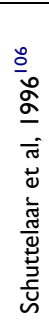 & 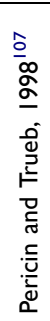 & 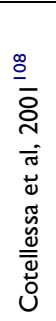 & 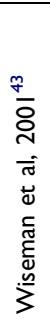 & 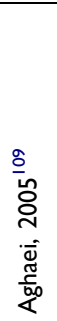 \\
\hline
\end{tabular}




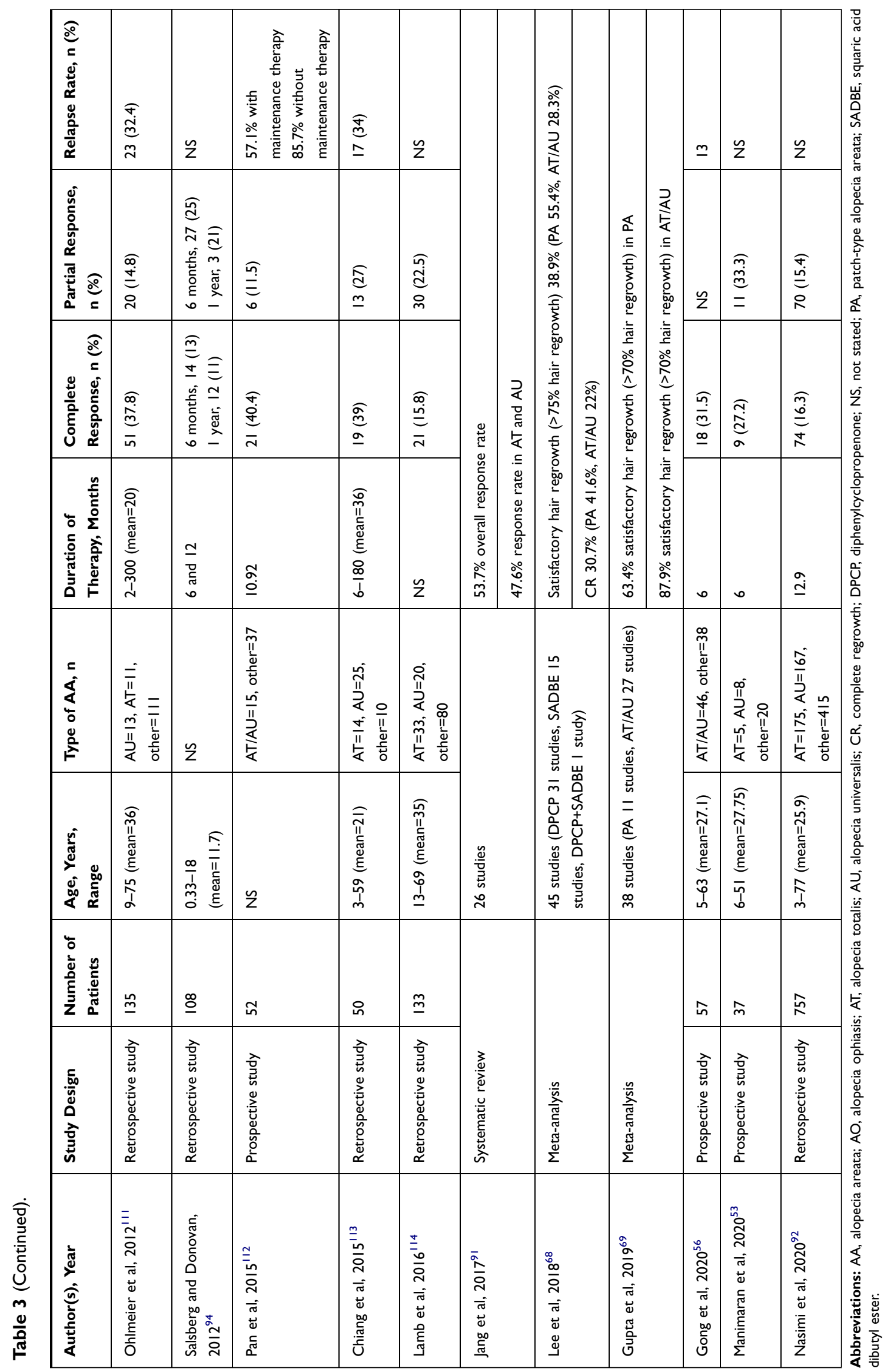


imiquimod, however, superior efficacy of combination therapy to DPCP monotherapy was evident. ${ }^{120}$ Clinical trials using DPCP as a combination therapy for AA are listed in Table $4 .^{115-120}$

\section{Modified Protocol of Diphenylcyclopropenone}

Since the standard treatment protocol of contact sensitizers may take a long time until acceptable treatment response is achieved, modified protocols have been introduced to address this issue. Sriphojanart et al and Thuangtong et al had reported the use of a multiconcentration DPCP treatment on patients' scalps at the first visit. ${ }^{121,122}$ A concentration that created an optimal eczematous reaction would then be selected as the starting solution for application. Multi-concentration protocol showed similar efficacy as the standard protocol, with a shorter duration till significant hair regrowth is

Table 4 Characteristics of Clinical Studies Using Combination Therapy and Modified Protocol of Diphenylcyclopropenone for the Treatment of Alopecia Areata

\begin{tabular}{|c|c|c|c|c|}
\hline Author(s), Year & Study Design & Type of AA, $n$ & Treatment & Results \\
\hline \multicolumn{5}{|c|}{ Combination therapy of DPCP } \\
\hline $\begin{array}{l}\text { Shapiro et al, } \\
1993^{119}\end{array}$ & RCT & $>50 \% A A=15$ & $\begin{array}{l}\text { DPCP with placebo vs DPCP with } 5 \% \\
\text { minoxidil }\end{array}$ & $\begin{array}{l}\text { DPCP alone: } 42.8 \% \text { response rate } \\
\text { DPCP with } 5 \% \text { minoxidil: } 33.33 \% \\
\text { response rate }\end{array}$ \\
\hline $\begin{array}{l}\text { Durdu et al, } \\
2015^{115}\end{array}$ & $\begin{array}{l}\text { Retrospective } \\
\text { study }\end{array}$ & $>50 \% \mathrm{AA}=47$ & $\begin{array}{l}\text { DPCP alone } 22 \text { patients vs DPCP with } \\
0.5 \% \text { anthralin } 25 \text { patients }\end{array}$ & $\begin{array}{l}\text { DPCP alone: } 36.4 \% \text { CR } \\
\text { DPCP with } 0.5 \% \text { anthralin: } 72 \% \text { CR }\end{array}$ \\
\hline $\begin{array}{l}\text { Wasylyszyn and } \\
\text { Borowska, } 2017^{120}\end{array}$ & $\begin{array}{l}\text { Prospective } \\
\text { study }\end{array}$ & Nonresponders $=20$ & $\begin{array}{l}\text { DPCP alone } 10 \text { patients vs DPCP with } 5 \% \\
\text { topical imiquimod } 10 \text { patients }\end{array}$ & $\begin{array}{l}\text { DPCP alone: } 40 \% \text { PR } \\
\text { DPCP with } 5 \% \text { topical imiquimod: } \\
50 \% \text { CR and } 40 \% \text { PR }\end{array}$ \\
\hline $\begin{array}{l}\text { Nasimi et al, } \\
2019^{118}\end{array}$ & $\begin{array}{l}\text { Retrospective } \\
\text { case series }\end{array}$ & Nonresponders $=32$ & DPCP and $0.5 \%$ anthralin & $\begin{array}{l}40.62 \% \text { response rate } \\
27.27 \% \text { achieved }>50 \% \text { hair regrowth }\end{array}$ \\
\hline $\begin{array}{l}\text { Ibrahim et al, } \\
2019^{116}\end{array}$ & $\begin{array}{l}\text { Prospective } \\
\text { study }\end{array}$ & $>50 \% \mathrm{AA}=24$ & $\begin{array}{l}\text { DPCP alone } 12 \text { patients vs DPCP with } \\
\text { anthralin } 12 \text { patients }\end{array}$ & $\begin{array}{l}\text { DPCP alone: CR } 62.5 \% \\
\text { DPCP with anthralin: CR } 18.2 \%\end{array}$ \\
\hline $\begin{array}{l}\text { Kagami et al, } \\
2020^{117}\end{array}$ & Case series & Refractory $\mathrm{AA}=4$ & $2 \%$ DPCP or SADBE with $0.5 \%$ anthralin & $\begin{array}{l}25 \% \mathrm{CR} \\
25 \% \mathrm{PR} \\
50 \% \text { no response }\end{array}$ \\
\hline \multicolumn{5}{|c|}{ Modified protocol of DPCP } \\
\hline $\begin{array}{l}\text { Sriphojanart et al, } \\
2017^{121}\end{array}$ & $\begin{array}{l}\text { Retrospective } \\
\text { study }\end{array}$ & 39 & $\begin{array}{l}\text { Standard regimen } 23 \text { patients vs new } \\
\text { regimen } 16 \text { patients }\end{array}$ & $\begin{array}{l}\text { Standard regimen: } 52 \% \text { response rate } \\
\text { New treatment regimen: } 50 \% \\
\text { response rate }\end{array}$ \\
\hline $\begin{array}{l}\text { Thuangtong et al, } \\
2017^{122}\end{array}$ & $\begin{array}{l}\text { Prospective } \\
\text { study }\end{array}$ & $\mathrm{AT} / \mathrm{AU}=\mathbf{2 0}$ & $\begin{array}{l}\text { Standard regimen vs multilevel DPCP } \\
\text { concentration }\end{array}$ & $25 \%$ CR within 34 weeks \\
\hline $\begin{array}{l}\text { Lee and Lee, } \\
2018^{124}\end{array}$ & $\begin{array}{l}\text { Retrospective } \\
\text { study }\end{array}$ & 80 & $\begin{array}{l}\text { Home-based treatment: } 40 \text { patients vs } \\
\text { clinic-based treatment: } 40 \text { patients }\end{array}$ & $\begin{array}{l}\text { Home-based treatment: } 45 \% \\
\text { response rate } \\
\text { Clinic-based treatment: } 45 \% \text { response } \\
\text { rate }\end{array}$ \\
\hline $\begin{array}{l}\text { Nowicka et al, } \\
2018^{123}\end{array}$ & $\begin{array}{l}\text { Prospective } \\
\text { study }\end{array}$ & $39(\mathrm{AT}=9)$ & $\begin{array}{l}\text { DPCP I-week interval } 16 \text { patients vs } \\
\text { DPCP } 3 \text {-week interval } 23 \text { patients }\end{array}$ & $\begin{array}{l}\text { DPCP I-week interval: } 46 \% \text { mean } \\
\text { response rate } \\
\text { DPCP 3-week interval: } 54 \% \text { mean } \\
\text { response rate }\end{array}$ \\
\hline Kim et al, $2020^{125}$ & $\begin{array}{l}\text { Retrospective } \\
\text { study }\end{array}$ & 204 & $\begin{array}{l}\text { Home-based treatment } 5 \mathrm{I} \text { patients vs } \\
\text { clinic-based treatment } 153 \text { patients }\end{array}$ & $\begin{array}{l}\text { Significantly lower loss-to-follow-up } \\
\text { rate in home-based treatment }\end{array}$ \\
\hline
\end{tabular}

Abbreviations: AA, alopecia areata; AT, alopecia totalis; AU, alopecia universalis; RCT, randomized controlled trial; CR, complete regrowth; DPCP, diphenylcyclopropenone; SADBE, squaric acid dibutyl ester; PR, partial response. 
achieved. ${ }^{121}$ Another study had also investigated the efficacy across various application intervals. Results showed the threeweek treated group to have higher efficacy than the one-week interval group, with $54 \%$ and $46 \%$ response rates, respectively. ${ }^{123}$ A subsequent retrospective study reported no significant difference of efficacy between home-based DPCP therapy and clinic-based therapy; however, the homebased group had better compliance compared to the clinicbased group. ${ }^{124}$ Clinical trials using modified DPCP therapy for the treatment of AA have been listed in Table 4. ${ }^{121-125}$

Although DPCP is the best-documented treatment for extensive or recalcitrant AA, not all patients achieve a good response, and some might withdraw due to adverse effects. Patients with high serum IgE levels may have more severe adverse events following DPCP application. ${ }^{56}$ Regarding safety, most patients were found to be tolerant to DPCP and no systemic absorption has yet been reported. ${ }^{105}$ Most adverse effects have been recorded without long-term complications; common side effects include dermatitis and urticaria. ${ }^{89,98,103-105,108,111,126}$ Angioedema, anaphylaxis, fever, erythema multiforme-like reactions, postinflammatory hypopigmentation, and depigmentation have been reported as infrequent complications. ${ }^{99,100,127-129}$

\section{Conclusion}

Topical immunotherapy is currently considered as the firstline treatment, representing the most effective modality for treating extensive or recalcitrant AA. DPCP and SADBE are currently prescribed as sensitizing agents with appreciable tolerability. Despite being commonly used, the exact mechanism underlying topical immunotherapy for the treatment of AA has not yet been elucidated. Accumulating evidence has shown advantage of topical immunotherapy over no treatment; however, comparison of the efficacies across different clinical studies and different substances is difficult owing to variations of treatment protocols, evaluation methods, and study durations. In our opinion, topical immunotherapy, when used with caution, is an effective and safe treatment. Further studies would be essential for the better understanding of pathophysiology of AA, roles of cytokines for predicting disease and treatment outcomes, and precise pathways via which sensitizing agents function, eventually helping in the establishment of a more effective treatment for individuals with AA.

\section{Disclosure}

The authors report no conflicts of interest in this work.

\section{References}

1. Paus R, Slominski A, Czarnetzki BM. Is alopecia areata an autoimmune-response against melanogenesis-related proteins, exposed by abnormal MHC class I expression in the anagen hair bulb? Yale J Biol Med. 1993;66(6):541-554.

2. Khunkhet S, Vachiramon V, Suchonwanit P. Trichoscopic clues for diagnosis of alopecia areata and trichotillomania in Asians. Int J Dermatol. 2017;56(2):161-165. doi:10.1111/ijd.13453

3. Pratt $\mathrm{CH}$, King LE Jr, Messenger AG, Christiano AM, Sundberg JP. Alopecia areata. Nat Rev Dis Primers. 2017;3 (1):17011. doi:10.1038/nrdp.2017.11

4. Kassira S, Korta DZ, Chapman LW, Dann F. Review of treatment for alopecia totalis and alopecia universalis. Int $J$ Dermatol. 2017;56(8):801-810. doi:10.1111/ijd.13612

5. MacDonald Hull SP, Wood ML, Hutchinson PE, Sladden M, Messenger AG. British association of Dermatologists' guidelines for the management of alopecia areata. Br J Dermatol. 2003;149 (4):692-699. doi:10.1046/j.1365-2133.2003.05535.x

6. Suchonwanit P, Kositkuljorn C, Mahasaksiri T, Leerunyakul K. A comparison of the efficacy and tolerability of three corticosteroid treatment regimens in patients with alopecia areata. J Dermatolog Treat. 2020. 1-6. doi:10.1080/09546634.2020. 1773384.

7. Triyangkulsri K, Suchonwanit P. Role of janus kinase inhibitors in the treatment of alopecia areata. Drug Des Devel Ther. 2018;12:2323-2335. doi:10.2147/DDDT.S172638

8. Meephansan J, Thummakriengkrai J, Ponnikorn S, Yingmema W, Deenonpoe R, Suchonwanit P. Efficacy of topical tofacitinib in promoting hair growth in non-scarring alopecia: possible mechanism via VEGF induction. Arch Dermatol Res. 2017;309 (9):729-738. doi:10.1007/s00403-017-1777-5

9. Chanasumon N, Sriphojanart T, Suchonwanit P. Therapeutic potential of bimatoprost for the treatment of eyebrow hypotrichosis. Drug Des Devel Ther. 2018;12:365-372. doi:10. 2147/DDDT.S156467

10. Suchonwanit $P$, Thammarucha S, Leerunyakul K. Minoxidil and its use in hair disorders: a review. Drug Des Devel Ther. 2019;13:2777-2786. doi:10.2147/DDDT.S214907

11. Liu LY, King BA, Craiglow BG. Health-related quality of life (HRQoL) among patients with alopecia areata (AA): a systematic review. J Am Acad Dermatol. 2016;75(4):806-812.e803. doi:10. 1016/j.jaad.2016.04.035

12. Rencz F, Gulacsi L, Pentek M, Wikonkal N, Baji P, Brodszky V. Alopecia areata and health-related quality of life: a systematic review and meta-analysis. Br J Dermatol. 2016;175(3):561-571. doi:10.1111/bjd.14497

13. Rattananukrom $T$, Suchonwanit $P$. Are drug treatment strategies really effective against alopecia areata? Expert Opin Pharmacother. 2020;22 (3):257-260. doi:10.1080/14656566.2020.1854728

14. Rokhsar CK, Shupack JL, Vafai JJ, Washenik K. Efficacy of topical sensitizers in the treatment of alopecia areata. $J \mathrm{Am}$ Acad Dermatol. 1998;39(5):751-761. doi:10.1016/S0190-962 2(98)70048-9

15. Petukhova L, Duvic M, Hordinsky M, et al. Genome-wide association study in alopecia areata implicates both innate and adaptive immunity. Nature. 2010;466(7302):113-117. doi:10.1038/ nature 09114

16. Gregoriou S, Papafragkaki D, Kontochristopoulos G, Rallis E, Kalogeromitros D, Rigopoulos D. Cytokines and other mediators in alopecia areata. Mediators Inflamm. 2010;2010:928030. doi:10. $1155 / 2010 / 928030$

17. Christoph T, Muller-Rover S, Audring H, et al. The human hair follicle immune system: cellular composition and immune privilege. Br J Dermatol. 2000;142(5):862-873. doi:10.1046/ j.1365-2133.2000.03464.x 
18. Kang H, Wu WY, Lo BK, et al. Hair follicles from alopecia areata patients exhibit alterations in immune privilege-associated gene expression in advance of hair loss. J Invest Dermatol. 2010;130 (11):2677-2680. doi:10.1038/jid.2010.180

19. Arca E, Musabak U, Akar A, Erbil AH, Tastan HB. Interferongamma in alopecia areata. Eur J Dermatol. 2004;14(1):33-36.

20. Sato-Kawamura M, Aiba S, Tagami H. Strong expression of CD40, CD54 and HLA-DR antigen and lack of evidence for direct cellular cytotoxicity are unique immunohistopathological features in alopecia areata. Arch Dermatol Res. 2003;294 (12):536-543. doi:10.1007/s00403-002-0354-7

21. Leerunyakul K, Suchonwanit P. Asian hair: a Review of structures, properties, and distinctive disorders. Clin Cosmet Investig Dermatol. 2020;13:309-318. doi:10.2147/CCID.S247390

22. Suchonwanit P, McMichael AJ. Alopecia in association with malignancy: a Review. Am J Clin Dermatol. 2018;19 (6):853-865. doi:10.1007/s40257-018-0378-1

23. Natpracha W, Sukanjanapong S, Chanprapaph K, Suchonwanit P. Characterization and classification of different female hairline patterns in the Thai population. J Cosmet Dermatol. 2021;20 (3):890-896. doi:10.1111/jocd.13642

24. Chanprapaph K, Tankunakorn J, Suchonwanit P, Rutnin S. Dermatologic manifestations, histologic features and disease progression among cutaneous lupus erythematosus subtypes: a prospective observational study in asians. Dermatol Ther (Heidelb). 2021;11(1):131-147. doi:10.1007/s13555-020-004 $71-\mathrm{y}$

25. Chanprapaph K, Pratumchart N, Limtong $P$, et al. Dipeptidyl peptidase-4 inhibitor-related bullous pemphigoid: a comparative study of 100 patients with bullous pemphigoid and diabetes mellitus. J Dermatol. 2021. doi:10.1111/13468138.15778

26. Chanprapaph K, Tubtieng I, Pratumchat N, Thadanipon K, Rattanakaemakorn P, Suchonwanit P. Cutaneous, systemic features and laboratory characteristics of late- versus adult-onset systemic lupus erythematosus in 1006 Thai patients. Lupus. 2021;961203321991920. doi:10.1177/0961203321991920

27. Rojhirunsakool S, Suchonwanit P. Parietal scalp is another affected area in female pattern hair loss: an analysis of hair density and hair diameter. Clin Cosmet Investig Dermatol. 2018;11:7-12. doi:10.2147/CCID.S153768

28. Paus R, Bertolini M. The role of hair follicle immune privilege collapse in alopecia areata: status and perspectives. J Investig Dermatol Symp Proc. 2013;16(1):S25-27. doi:10.1038/jidsymp. 2013.7

29. Teraki Y, Imanishi K, Shiohara T. Cytokines in alopecia areata: contrasting cytokine profiles in localized form and extensive form (alopecia universalis). Acta Derm Venereol. 1996;76(6):421-423. doi:10.2340/0001555576421423

30. Lee D, Hong SK, Park SW, et al. Serum levels of IL-18 and SIL-2R in patients with alopecia areata receiving combined therapy with oral cyclosporine and steroids. Exp Dermatol. 2010;19 (2):145-147. doi:10.1111/j.1600-0625.2009.00937.x

31. Katagiri K, Arakawa S, Hatano Y. In vivo levels of IL-4, IL-10, TGF-beta1 and IFN-gamma mRNA of the peripheral blood mononuclear cells in patients with alopecia areata in comparison to those in patients with atopic dermatitis. Arch Dermatol Res. 2007;298(8):397-401. doi:10.1007/s00403-006-0700-2

32. Bodemer C, Peuchmaur M, Fraitaig S, Chatenoud L, Brousse N, De Prost Y. Role of cytotoxic T cells in chronic alopecia areata. $J$ Invest Dermatol. 2000;114(1):112-116. doi:10.1046/j.15231747.2000.00828.x

33. Kryczek I, Wei S, Gong W, et al. Cutting edge: IFN-gamma enables APC to promote memory Th17 and abate Th1 cell development. J Immunol. 2008;181(9):5842-5846. doi:10.4049/ jimmunol.181.9.5842
34. Hoffmann R, Wenzel E, Huth A, et al. Cytokine mRNA levels in Alopecia areata before and after treatment with the contact allergen diphenylcyclopropenone. J Invest Dermatol. 1994;103 (4):530-533. doi:10.1111/1523-1747.ep12395722

35. Barahmani N, Lopez A, Babu D, Hernandez M, Donley SE, Duvic M. Serum T helper 1 cytokine levels are greater in patients with alopecia areata regardless of severity or atopy. Clin Exp Dermatol. 2010;35(4):409-416. doi:10.1111/j.1365-2230.2009.03 523. $\mathrm{x}$

36. Suchonwanit P, Hector CE, Bin Saif GA, McMichael AJ. Factors affecting the severity of central centrifugal cicatricial alopecia. Int J Dermatol. 2016;55(6):e338-343. doi:10.1111/ijd.13061

37. Shohat M, Mimouni D, Ben-Amitai D, et al. In vitro cytokine profile in childhood alopecia areata and the immunomodulatory effects of AS-101. Clin Exp Dermatol. 2005;30(4):432-434. doi:10.1111/j.1365-2230.2005.01817.x

38. Harnchoowong S, Suchonwanit P. PPAR- $\gamma$ agonists and their role in primary cicatricial alopecia. PPAR Res. 2017;2017:2501248. doi:10.1155/2017/2501248

39. Suchonwanit P, Chalermroj N, Khunkhet S. Low-level laser therapy for the treatment of androgenetic alopecia in Thai men and women: a 24-week, randomized, double-blind, sham device-controlled trial. Lasers Med Sci. 2019;34(6):1107-1114. doi:10.1007/s10103-01802699-9

40. Suchonwanit P, Rojhirunsakool S, Khunkhet S. A randomized, investigator-blinded, controlled, split-scalp study of the efficacy and safety of a 1550-nm fractional erbium-glass laser, used in combination with topical 5\% minoxidil versus 5\% minoxidil alone, for the treatment of androgenetic alopecia. Lasers Med Sci. 2019;34(9):1857-1864. doi:10.1007/s10103-019-02783-8

41. Suchonwanit $\mathrm{P}$, Thammarucha $\mathrm{S}$. Eyebrow growth pattern analysis in patients with eyebrow hypotrichosis after receiving topical treatment: a retrospective study. J Cosmet Dermatol. 2020;19 (6):1404-1408. doi:10.1111/jocd.13167

42. Messenger AG, McKillop J, Farrant P, McDonagh AJ, Sladden M. British association of Dermatologists' guidelines for the management of alopecia areata 2012. Br J Dermatol. 2012;166(5):916-926. doi:10.1111/j.1365-2133.2012.10955.x

43. Wiseman MC, Shapiro J, MacDonald N, Lui H. Predictive model for immunotherapy of alopecia areata with diphencyprone. Arch Dermatol. 2001;137(8):1063-1068.

44. Suchonwanit P, Iamsumang W, Rojhirunsakool S. Efficacy of topical combination of $0.25 \%$ finasteride and $3 \%$ minoxidil versus $3 \%$ minoxidil solution in female pattern hair Loss: a Randomized, Double-Blind, Controlled Study. Am J Clin Dermatol. 2019;20 (1):147-153. doi:10.1007/s40257-018-0387-0

45. Buckley DA, Du Vivier AW. The therapeutic use of topical contact sensitizers in benign dermatoses. $\mathrm{Br} J$ Dermatol. 2001;145(3):385-405. doi:10.1046/j.1365-2133.2001.04399.x

46. Sutherland L, Laschinger M, Syed ZU, Gaspari A. Treatment of alopecia areata with topical sensitizers. Dermatitis. 2015;26 (1):26-31. doi:10.1097/DER.0000000000000094

47. Happle R. Antigenic competition as a therapeutic concept for alopecia areata. Arch Dermatol Res. 1980;267(1):109-114. doi:10.1007/BF00416931

48. Zoller M, Freyschmidt-Paul P, Vitacolonna M, McElwee KJ, Hummel S, Hoffmann R. Chronic delayed-type hypersensitivity reaction as a means to treat alopecia areata. Clin Exp Immunol. 2004;135(3):398-408. doi:10.1111/j.1365-2249.2003.02380.x

49. Herbst V, Zoller M, Kissling S, Wenzel E, Stutz N, FreyschmidtPaul P. Diphenylcyclopropenone treatment of alopecia areata induces apoptosis of perifollicular lymphocytes. Eur J Dermatol. 2006;16(5):537-542.

50. Kuwano Y, Fujimoto M, Watanabe R, et al. Serum chemokine profiles in patients with alopecia areata. Br J Dermatol. 2007;157 (3):466-473. doi:10.1111/j.1365-2133.2007.07943.x 
51. Gulati N, Suarez-Farinas M, Fuentes-Duculan J, et al. Molecular characterization of human skin response to diphencyprone at peak and resolution phases: therapeutic insights. J Invest Dermatol. 2014;134(10):2531-2540. doi:10.1038/jid.2014.196

52. Zoller M, McElwee KJ, Vitacolonna M, Hoffmann R. The progressive state, in contrast to the stable or regressive state of alopecia areata, is reflected in peripheral blood mononuclear cells. Exp Dermatol. 2004;13(7):435-444. doi:10.1111/j.09066705.2004.00179.x

53. Manimaran RP, Ramassamy S, Rajappa M, Chandrashekar L. Therapeutic outcome of diphencyprone and its correlation with serum cytokine profile in alopecia areata. $J$ Dermatolog Treat. 2020;1-5. doi:10.1080/09546634.2020.1752887

54. Konig A, Happle R, Hoffmann R. IFN-gamma-induced HLA-DR but not ICAM-1 expression on cultured dermal papilla cells is downregulated by TNF-alpha. Arch Dermatol Res. 1997;289 (8):466-470. doi:10.1007/s004030050222

55. Lee SH, Moon JH, Ban DH, Byun JW, Shin J, Choi GS. Can the cytokine analysis of the scales on alopecic patch predict the response to diphenylcyclopropenone treatment in Alopecia Areata patients? Ann Dermatol. 2018;30(2):150-157. doi:10.50 21/ad.2018.30.2.150

56. Gong Y, Zhao Y, Zhang X, et al. Serum level of IL-4 predicts response to topical immunotherapy with diphenylcyclopropenone in alopecia areata. Exp Dermatol. 2020;29(3):231-238. doi:10.11 11/exd. 13758

57. Stute J, Hausen BM, Schulz KH. [Diphenylcyclopropenone a new strong contact sensitizer]. Derm Beruf Umwelt. 1981;29 (1):12-14. German.

58. Strazzulla LC, Wang EHC, Avila L, et al. Alopecia areata: an appraisal of new treatment approaches and overview of current therapies. J Am Acad Dermatol. 2018;78(1):15-24. doi:10.1016/j. jaad.2017.04.1142

59. Higgins E, Du Vivier A. Topical immunotherapy: unapproved uses, dosages, or indications. Clin Dermatol. 2002;20(5):51 5-521. doi:10.1016/S0738-081X(02)00272-9

60. Black HS, Castrow FF 2nd, Gerguis J. The mutagenicity of dinitrochlorobenzene. Arch Dermatol. 1985;121(3):348-349. doi:10.1001/archderm.1985.01660030070021

61. Breuillard F, Szapiro E. Dinitrochlorobenzene in alopecia areata. Lancet. 1978;312(8103):1304. doi:10.1016/S0140-6736(78)92059-7

62. Friedmann PS. Response of alopecia areata to DNCB: influence of auto-antibodies and route of sensitization. $\mathrm{Br} J$ Dermatol. 1981;105(3):285-289. doi:10.1111/j.1365-2133.1981.tb01287.x

63. Swanson NA, Mitchell AJ, Leahy MS, Headington JT, Diaz LA. Topical treatment of alopecia areata. Arch Dermatol. 1981;117 (7):384-387. doi:10.1001/archderm.1981.01650070012011

64. Singla A, Mittal RR, Walia RLS, Bansal IJS. Comparative efficacy of topical DNCB and PUVASOL therapy in alopecia areata. Indian J Dermatol Venereol Leprol. 1991;57.

65. Yoshizawa Y, Izaki S, Kitamura K, Kawana S. Systemic immunotherapy with topical dinitrochlorobenzene as additional treatment of alopecia areata. Acta Derm Venereol. 2002;82(2):1 36-138. doi:10.1080/00015550252948202

66. Happle R, Kalveram KJ, Büchner U, Echternacht-Happle K, Göggelmann W, Summer KH. Contact allergy as a therapeutic tool for alopecia areata: application of squaric acid dibutylester. Dermatologica. 1980;161(5):289-297. doi:10.1159/000250380

67. Wilkerson MG, Henkin J, Wilkin JK, Smith RG. Squaric acid and esters: analysis for contaminants and stability in solvents. $J \mathrm{Am}$ Acad Dermatol. 1985;13(2):229-234. doi:10.1016/S0190-9622 (85)70164-8

68. Lee S, Kim BJ, Lee YB, Lee WS. Hair regrowth outcomes of contact immunotherapy for patients with Alopecia Areata: a systematic review and meta-analysis. JAMA Dermatol. 2018;154(10):1145-1151. doi:10.1001/jamadermatol.2018.2312
69. Gupta AK, Carviel JL, Foley KA, et al. Monotherapy for Alopecia Areata: a systematic Review and network meta-analysis. Skin Appendage Disord. 2019;5(6):331-337. doi:10.1159/000501940

70. Tosti A, Caponeri GM, Primativo R, Melino M, Veronesi S. Squaric acid dibutyl ester and diphencyprone in the therapy of alopecia areata. G Ital Dermatol Venereol. 1985;120(5):371-373.

71. Micali G, Cicero RL, Nasca MR, Sapuppo A. Treatment of alopecia areata with squaric acid dibutylester. Int $J$ Dermatol. 1996;35(1):52-56. doi:10.1111/j.1365-4362.1996.tb01618.x

72. Dall'oglio F, Nasca MR, Musumeci ML, et al. Topical immunomodulator therapy with squaric acid dibutylester (SADBE) is effective treatment for severe alopecia areata (AA): results of an open-label, paired-comparison, clinical trial. $J$ Dermatolog Treat. 2005;16(1):10-14. doi:10.1080/09546630410023601

73. Chua SH, Goh CL, Ang CB. Topical squaric acid dibutylester therapy for alopecia areata: a double-sided patient-controlled study. Ann Acad Med Singapore. 1996;25(6):842-847.

74. Caserio RJ. Treatment of alopecia areata with squaric acid dibutylester. Arch Dermatol. 1987;123(8):1036-1041. doi:10.10 01/archderm.1987.01660320078016

75. Giannetti A, Orecchia G. Clinical experience on the treatment of alopecia areata with squaric acid dibutyl ester. Dermatologica. 1983;167(5):280-282. doi:10.1159/000249797

76. Tosti A, De Padova MP, Minghetti G, Veronesi S. Therapies versus placebo in the treatment of patchy alopecia areata. $J \mathrm{Am}$ Acad Dermatol. 1986;15(2):209-210. doi:10.1016/S0190-962 2(86)70158-8

77. Johansson E, Ranki A, Reunala T, Kianto U, Niemi KM. Immunohistological evaluation of alopecia areata treated with squaric acid dibutylester (SADBE). Acta Derm Venereol. 1986;66(6):485-490.

78. Orecchia G, Rabbiosi G. Patterns of hair regrowth in alopecia areata. Dermatologica. 1988;176(5):270-272. doi:10.1159/000248718

79. Orecchia G, Malagoli P, Santagostino L. Treatment of severe alopecia areata with squaric acid dibutylester in pediatric patients. Pediatr Dermatol. 1994;11(1):65-68. doi:10.1111/j.15 25-1470.1994.tb00078.x

80. Tosti A, Guidetti MS, Bardazzi F, Misciali C. Long-term results of topical immunotherapy in children with alopecia totalis or alopecia universalis. J Am Acad Dermatol. 1996;35(2):199-201. doi:10.1016/S0190-9622(96)90323-0

81. Iijima S, Otsuka F. Prognostic factors for clinical response of Alopecia Areata to topical immunotherapy with squaric acid dibutylester. Arch Dermatol. 1997;133(4):539-540. doi:10.1001/ archderm.133.4.539

82. Sakai K, Fukushima S, Mizuhashi S, et al. Effect of topical immunotherapy with squaric acid dibutylester for alopecia areata in Japanese patients. Allergol Int. 2019;69(2):274-278. doi:10.10 16/j.alit.2019.10.008

83. Chen CA, Carlberg V, Kroshinsky D. angioedema after squaric acid treatment in a 6-year-old girl. Pediatr Dermatol. 2017;34(1): e44-e46. doi:10.1111/pde. 12993

84. Nasca MR, Cicero RL, Innocenzi D, Micali G. Persistent allergic contact dermatitis at the site of primary sensitization with squaric acid dibutyl ester. Contact Dermatitis. 1995;33(6):438. doi:10.11 11/j.1600-0536.1995.tb02090.x

85. Todaro A, Nava C. Allergic disease caused by squaric acid dibutyl ester: description of 2 cases in a work environment. Med Lav. 1991;82(3):276-279.

86. Ujiie H, Sawamura D, Shibaki A, Shimizu H. Prolonged dermatitis distant to the site of squaric acid dibutyl ester applications and recovery of alopecia areata. Clin Exp Dermatol. 2005;30 (5):579-580. doi:10.1111/j.1365-2230.2005.01804.x

87. Valsecchi R, Pansera B, Rossi A, Cainelli T. Pigmentation abnormalities in the course of topical immunotherapy of alopecia areata. G Ital Dermatol Venereol. 1989;124(1-2):31-32. 
88. Valsecchi R, Cainelli T. Depigmentation from squaric acid dibutylester. Contact Dermatitis. 1984;10(2):109. doi:10.1111/ j.1600-0536.1984.tb00349.x

89. Happle R, Hausen BM, Wiesner-Menzel L. Diphencyprone in the treatment of alopecia areata. Acta Derm Venereol. 1983;63 (1):49-52.

90. Borowska K, Wasylyszyn T. Stability of solutions of 2,3-diphenylcyclopropenone in various solvents. A novel formula - diphenylcyclopropenone in isopropanol may be useful in topical therapy of patients with Alopecia Areata. Acta Pol Pharm. 2017;74(2):459-464.

91. Jang YH, Jung HJ, Moon SY, et al. Systematic review and quality analysis of studies on the efficacy of topical diphenylcyclopropenone treatment for alopecia areata. J Am Acad Dermatol. 2017;77 (1):170-172. doi:10.1016/j.jaad.2017.03.015

92. Nasimi M, Abedini R, Ghandi N, Seirafi H, Sadat Mehdizade M, Tootoonchi N. Topical immunotherapy with diphenylcyclopropenone in patients with alopecia areata: a large retrospective study of 757 patients. Dermatol Ther. 2020;33(6):e13808. doi:10.1111/dth.13808

93. Hull SM, Pepall L, Cunliffe WJ. Alopecia areata in children: response to treatment with diphencyprone. $\mathrm{Br} J$ Dermatol. 1991;125(2):164-168. doi:10.1111/j.1365-2133.1991.tb06064.x

94. Salsberg JM, Donovan J. The safety and efficacy of diphencyprone for the treatment of alopecia areata in children. Arch Dermatol. 2012;148(9):1084-1085. doi:10.1001/archdermatol.2012.1622

95. Choe SJ, Lee S, Lee H, Choi J, Lee WS. Efficacy of topical diphenylcyclopropenone maintenance treatment for patients with alopecia areata: a retrospective study. $\mathrm{J} \mathrm{Am}$ Acad Dermatol. 2018;78(1):205-207 e201. doi:10.1016/j.jaad.2017.07.028

96. HullSM, Cunliffe WJ. Post-therapy relapse rate in alopecia areata after successful treatment with diphencyprone. $J$ Dermatolog Treat. 1989;1(2):71-74.

97. van der Steen PH, Boezeman JB, Happle R. Topical immunotherapy for alopecia areata: re-evaluation of 139 cases after an additional follow-up period of 19 months. Dermatology. 1992;184 (3):198-201. doi:10.1159/000247540

98. Hull SM, Norris JF. Diphencyprone in the treatment of long-standing alopecia areata. $\mathrm{Br} \quad J$ Dermatol. 1988;119 (3):367-374. doi:10.1111/j.1365-2133.1988.tb03230.x

99. Hatzis J, Georgiotouo K, Kostakis P, et al. Treatment of alopecia areata with diphencyprone. Australas J Dermatol. 1988;29 (1):33-36. doi:10.1111/j.1440-0960.1988.tb01223.x

100. Monk B. Induction of hair growth in alopecia totalis with diphencyprone sensitization. Clin Exp Dermatol. 1989;14(2):154-157. doi:10.1111/j.1365-2230.1989.tb00915.x

101. Ashworth J, Tuyp E, Mackie RM. Allergic and irritant contact dermatitis compared in the treatment of alopecia totalis and universalis. A comparison of the value of topical diphencyprone and tretinoin gel. Br J Dermatol. 1989;120(3):397-401. doi:10.1111/ j.1365-2133.1989.tb04166.x

102. Hull SM, Cunliffe WJ. Successful treatment of alopecia areata using the contact allergen diphencyprone. $\mathrm{Br} J$ Dermatol. 1991;124(2):212-213. doi:10.1111/j.1365-2133.1991.tb00443.x

103. van der Steen PH, van Baar HM, Perret CM, Happle R. Treatment of alopecia areata with diphenylcyclopropenone. $J$ Am Acad Dermatol. 1991;24(2):253-257. doi:10.1016/0190-9622(91)70037-3

104. Hoting E, Boehm A. Therapy of alopecia areata with diphencyprone. Br J Dermatol. 1992;127(6):625-629. doi:10.11 11/j.1365-2133.1992.tb14877.x

105. Gordon PM, Aldrige RD, McVittie E, Hunter JA. Topical diphencyprone for alopecia areata: evaluation of 48 cases after 30 months' follow-up. Br J Dermatol. 1996;134(5):869-871. doi:10. 1111/j.1365-2133.1996.tb06317.x

106. Schuttelaar ML, Hamstra JJ, Plinck EP, et al. Alopecia areata in children: treatment with diphencyprone. Br J Dermatol. 1996;135 (4):581-585. doi:10.1111/j.1365-2133.1996.tb03835.x
107. Pericin M, Trueb RM. Topical immunotherapy of severe alopecia areata with diphenylcyclopropenone: evaluation of 68 cases. Dermatology. 1998;196(4):418-421. doi:10.1159/000017935

108. Cotellessa C, Peris K, Caracciolo E, Mordenti C, Chimenti S. The use of topical diphenylcyclopropenone for the treatment of extensive alopecia areata. J Am Acad Dermatol. 2001;44(1):73-76. doi:10.1067/mjd.2001.109309

109. Aghaei S. Topical immunotherapy of severe alopecia areata with diphenylcyclopropenone (DPCP): experience in an Iranian population. BMC Dermatol. 2005;5(1):6. doi:10.1186/1471-5945-5-6

110. Avgerinou G, Gregoriou S, Rigopoulos D, Stratigos A, Kalogeromitros D, Katsambas A. Alopecia areata: topical immunotherapy treatment with diphencyprone. $J$ Eur Acad Dermatol Venereol. 2008;22(3):320-323. doi:10.1111/j.1468-3083.2007.02 411.x

111. Ohlmeier MC, Traupe H, Luger TA, Bohm M. Topical immunotherapy with diphenylcyclopropenone of patients with alopecia areata-a large retrospective study on 142 patients with a selfcontrolled design. J Eur Acad Dermatol Venereol. 2012;26 (4):503-507. doi:10.1111/j.1468-3083.2011.04114.x

112. Pan R, Liu J, Xuan X, Li B. Chinese experience in the treatment of alopecia areata with diphenylcyclopropenone. J Dermatol. 2015;42(2):220-221. doi:10.1111/1346-8138.12743

113. Chiang KS, Mesinkovska NA, Piliang MP, Bergfeld WF. Clinical efficacy of diphenylcyclopropenone in Alopecia Areata: retrospective data analysis of 50 patients. J Investig Dermatol Symp Proc. 2015;17(2):50-55. doi:10.1038/jidsymp.2015.28

114. Lamb RC, Young D, Holmes S. Retrospective review of diphencyprone in the treatment of alopecia areata. Clin Exp Dermatol. 2016;41(4):352-358. doi:10.1111/ced.12776

115. Durdu M, Ozcan D, Baba M, Seckin D. Efficacy and safety of diphenylcyclopropenone alone or in combination with anthralin in the treatment of chronic extensive alopecia areata: a retrospective case series. J Am Acad Dermatol. 2015;72(4):640-650. doi:10. 1016/j.jaad.2015.01.008

116. Ibrahim SA, Esawy AM, Abdelshafy AS. Treatment of chronic extensive alopecia areata by diphenylcyclopropenone alone versus in combination with anthralin. Dermatol Ther. 2019;32(5): e13010. doi:10.1111/dth.13010

117. Kagami S, Kishi Y, Hino H. Topical immunotherapy in combination with anthralin in the treatment of refractory alopecia areata. $J$ Cosmet Dermatol. 2020;19(9):2411-2414. doi:10.1111/jocd.13588

118. Nasimi M, Ghandi N, Abedini R, Mirshamsi A, Shakoei S, Seirafi H. Efficacy and safety of anthralin in combination with diphenylcyclopropenone in the treatment of alopecia areata: a retrospective case series. Arch Dermatol Res. 2019;311 (8):607-613. doi:10.1007/s00403-019-01940-x

119. Shapiro J, Tan J, Ho V, Abbott F, Tron V. Treatment of chronic severe alopecia areata with topical diphenylcyclopropenone and 5\% minoxidil: a clinical and immunopathologic evaluation. $J \mathrm{Am}$ Acad Dermatol. 1993;29(5):729-735. doi:10.1016/0190-9622(93) 70238-O

120. Wasylyszyn T, Borowska K. Possible advantage of imiquimod and diphenylcyclopropenone combined treatment versus diphenylcyclopropenone alone: an observational study of nonresponder patients with alopecia areata. Australas J Dermatol. 2017;58 (3):219-223. doi:10.1111/ajd.12478

121. Sriphojanart T, Khunkhet S, Suchonwanit P. A retrospective comparative study of the efficacy and safety of two regimens of diphenylcyclopropenone in the treatment of recalcitrant alopecia areata. Dermatol Reports. 2017;9(2):7399. doi:10.4081/dr.2017. 7399

122. Thuangtong R, Varothai S, Triwongwaranat D, Rujitharanawong C. Multi-concentration level patch test guided Diphenyl Cyclopropenone (DPCP) treatment in alopecia totalis or alopecia universalis. J Med Assoc Thai. 2017;100(1):86-92. 
123. Nowicka D, Maj J, Jankowska-Konsur A, HryncewiczGwozdz A. Efficacy of diphenylcyclopropenone in alopecia areata: a comparison of two treatment regimens. Postepy Dermatol Alergol. 2018;35(6):577-581. doi:10.5114/ ada.2018.77608

124. Lee S, Lee WS. Home-based contact immunotherapy with diphenylcyclopropenone for alopecia areata is as effective and safe as clinic-based treatment in patients with stable disease: a retrospective study of 40 patients. $J$ Am Acad Dermatol. 2018;78(3):599-601.e591. doi:10.1016/j.jaad.2017.09.037

125. Kim BJ, Lee S, Lee CH, Lee WS. Home-based contact immunotherapy with diphenylcyclopropenone improves compliance with the recommended follow-up for patients with alopecia areata: a retrospective cohort study. $J$ Am Acad Dermatol. 2020;82(5):1223-1225. doi:10.1016/j.jaad.2019.10.043
126. Francomano M, Seidenari S. Urticaria after topical immunotherapy with diphenylcyclopropenone. Contact Dermatitis. 2002;47 (5):310-311. doi:10.1034/j.1600-0536.2002.4705102.x

127. Sharma VK, Muralidhar S. Topical immunotherapy with diphencyprone in Indians with alopecia areata. Clin Exp Dermatol. 1998;23(6):291-292. doi:10.1046/j.1365-2230.1998.00254.x

128. Sanger J, Zahir A, Driscoll M, Gaspari AA. Erythema multiforme major after immunotherapy with diphenylcyclopropenone for Alopecia Areata. Dermatitis. 2018;29(6):348-349. doi:10.1097/ DER.0000000000000415

129. Buchanan R, Huynh G, Tanner J. Extensive scalp angioedema following high-dose diphenylcyclopropenone for alopecia areata. Hosp Pharm. 2014;49(1):48-51. doi:10.1310/hpj4901-48

\section{Publish your work in this journal}

Drug Design, Development and Therapy is an international, peerreviewed open-access journal that spans the spectrum of drug design and development through to clinical applications. Clinical outcomes, patient safety, and programs for the development and effective, safe, and sustained use of medicines are a feature of the journal, which has also been accepted for indexing on PubMed Central. The manuscrip management system is completely online and includes a very quick and fair peer-review system, which is all easy to use. Visit http://www. dovepress.com/testimonials.php to read real quotes from published authors. 